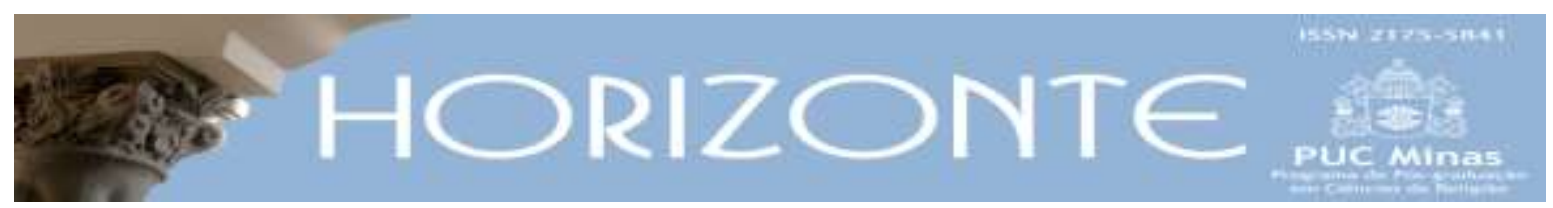

Comunicação

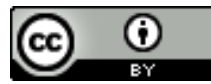

DOI - 10.5752/P.2175-5841.2016v14n44p1619

\title{
Deus e a religião em filósofos pós-modernos
}

\author{
God and religion in post-modern philosophers
}

José J. Queiroz *

\section{Resumo}

\begin{abstract}
O tema desta Comunicação é a religião em filósofos pós-modernos tendo como pano de fundo o debate sobre a pós-modernidade. Por isso, como objetivo preliminar, aborda-se a questão da pós-modernidade assumindo uma posição entre a simples aceitação e a recusa cabal da condição pós-moderna na atualidade. Nesta arena polêmica, focalizam-se importantes filósofos pós-modernos, apontando suas contribuições para um novo pensar sobre a religião hoje. O caminho ou método é a ida a alguns textos selecionados desses autores buscando uma leitura interpretativa dos seus discursos sobre Deus, a religião e o sagrado. Conclui-se que o pós-moderno não é uma nova era suplantando a modernidade, mas se constitui de temas novos caminhando à margem e amiúde em direção oposta aos parâmetros modernos. Estes temas se fazem presentes em vários campos do saber e do agir humano, inclusive na teologia e na ciência da religião, e o pensamento dos três autores implica um novo pensar sobre a religião na atualidade. Sobre a posição acerca da religião do filósofo mais focalizado, Jacques Derrida, o texto é ainda embrionário, pois integra uma pesquisa em andamento.
\end{abstract}

Palavras-chave: Pós-modernidade; Filósofos Pós-modernos; Deus; Religião; Sagrado.

\begin{abstract}
This paper is an essay on the positions of some post-modern philosophers on religion, with the debate about post-modernity as a background. Its preliminary objective is to situate post-modernity taking a position between plain acceptance and categorical refusal in contemporary society. In this polemical field, the paper focuses on three important post-modern philosophers by pointing their contributions for a new thinking about religion today. The procedure consists in the reading of the authors' texts looking for an interpretation of their discourses on God, religion and the sacred. The conclusion is that post-modernity is not as new era overcoming modernity, but that it is comprised of new themes that are on the fringes or even in opposite directions of modernity's parameters. One can find these themes in many fields of human knowledge including theology and science of religion. On Derrida's position, who is the most focused philosopher, the text is still embryonic as it comes from ongoing research.
\end{abstract}

Keywords: Post-modernity; Post-modern philosophers; God; Religion; Sacred.

Comunicação submetida em 10 de outubro de 2016 e aprovado em 25 de novembro de 2016.

* Doutor em Direito pela Universidade Pontificia Santo Tomás de Aquino de Roma (1960)m mestre (Lectoratus) em Filosofia e Teologia pela Faculdade Santo Tomás de Aquino de Boloha - Itália (1957) Professor titular da Pontifícia Universidade Católica de São Paulo. País de Origem: Brasil. E-mail: queiroz@pucsp.br

Horizonte, Belo Horizonte, v. 14, n. 44, p. 1619-1644, out./dez. 2016 - ISSN 2175-5841 


\section{Introdução}

A pós-modernidade, em que pesem as polêmicas em torno dela, tem ocupado espaço importante na varias áreas da ciência, inclusive nas ciências da religião e da teologia. Vários filósofos que se consideram ou são considerados pósmodernos abordam com frequência o tema Deus e a religião, cujas reflexões e posições merecem ser conhecidas, discutidas e até interpretadas.

A proposta deste texto é oferecer subsídios para esse debate. Na primeira parte, à guisa de introdução ao pós-moderno, adentra na polêmica "pósmodernidade sim ou não" e traz para a arena alguns autores que se posicionam pelo sim, outros que a rejeitam, e aponta uma posição intermediaria que possibilita captar no âmago da modernidade, que ainda persiste, temas que podem ser apontados como pós ou além da modernidade. Na segunda parte expõe perspectivas de três importantes filósofos pós-modernos que refletem sobre Deus e o fenômeno do novo impulso das religiões, assumindo características de relevância e novidade no debate sobre os rumos da religião na atualidade.

\section{PARTE I - INTRODUZINDO O PÓS-MODERNO}

\section{Pós-modernidade sim}

As posições que postulam a existência da pós-modernidade procedem por três vias: na cultura e na sociedade, na economia e na filosofia. Apresenta-se a seguir uma caracterização geral de forma sumária. ${ }^{1}$

\subsection{Na cultura e na sociedade em geral}

A pós-modernidade tem início como movimento cultural denominado pósmodernismo a partir dos anos 60 em reação ao modernismo cultural. A recusa era

${ }^{1}$ Algumas ideias seminais deste tema aparecem na Revista REVER no2- ano 6- 2006. 
por vários motivos, O modernismo tinha a pretensão de ser perfeito, especialmente na arquitetura. O arquiteto mais visado era o francês Le Corbusier (1887-1965). O modernismo era considerado elitista, autoritário, indiferente ao contexto de bairro e da comunidade. Desprezava as preferências dos homens comuns. Era arrogante.

Em oposição, o pós-modernismo cultural se declara eclético, plural, misturando vários estilos e tradições artísticas e aproximava elite e massa. O Shopping Center é amiúde apontado como exemplo de arquitetura e espaço pósmoderno, embora, dependendo da localização, nem todos aproximam elite e massa.

Figura 1 - Pintura pós-moderna - Andy Warhol - 1928-1987.

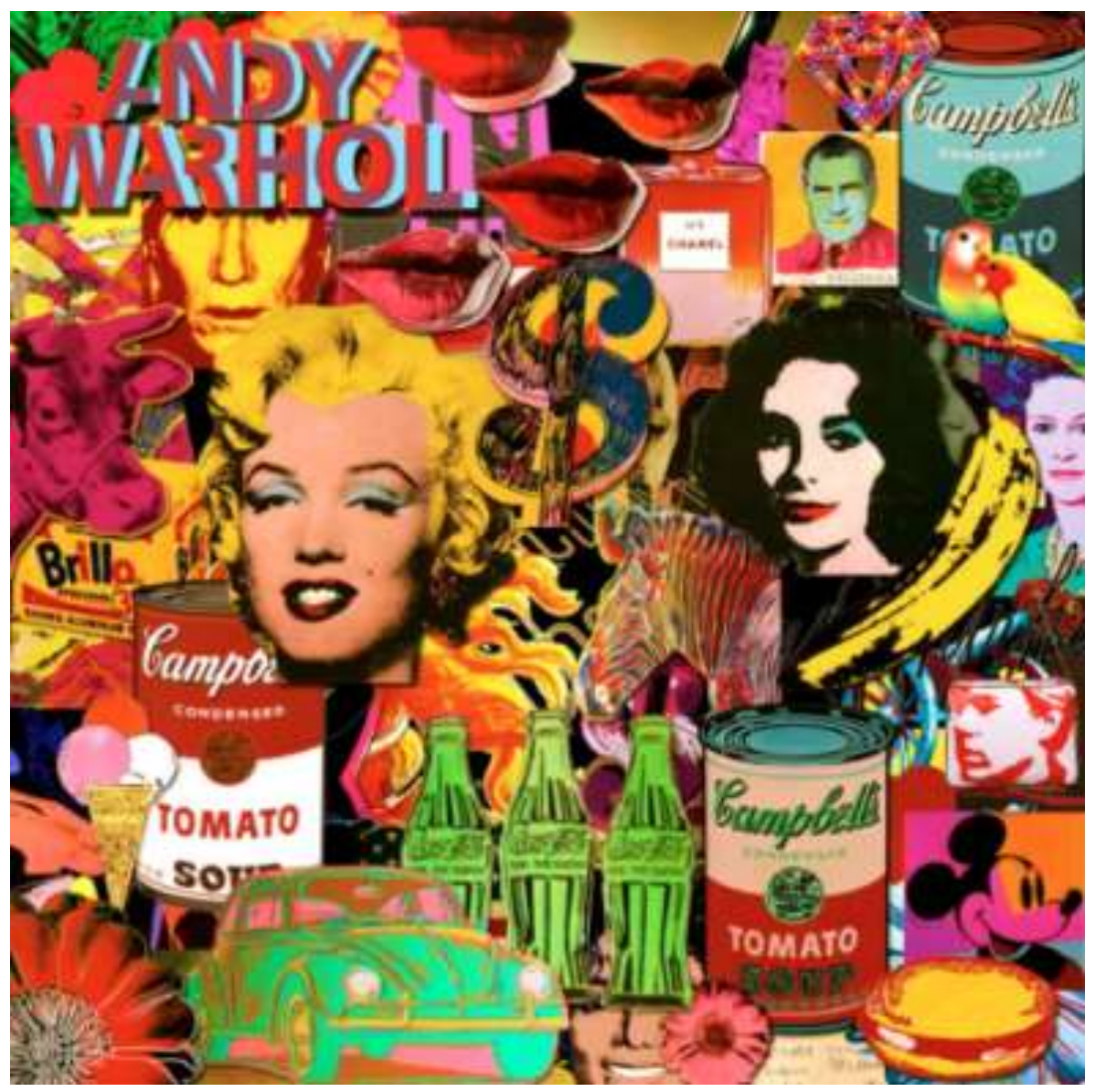

Fonte: ARTE, 2015. 
Figura 2 - O Lavrador de Café de Candido Torquato Portinari - 1903 - 1962.

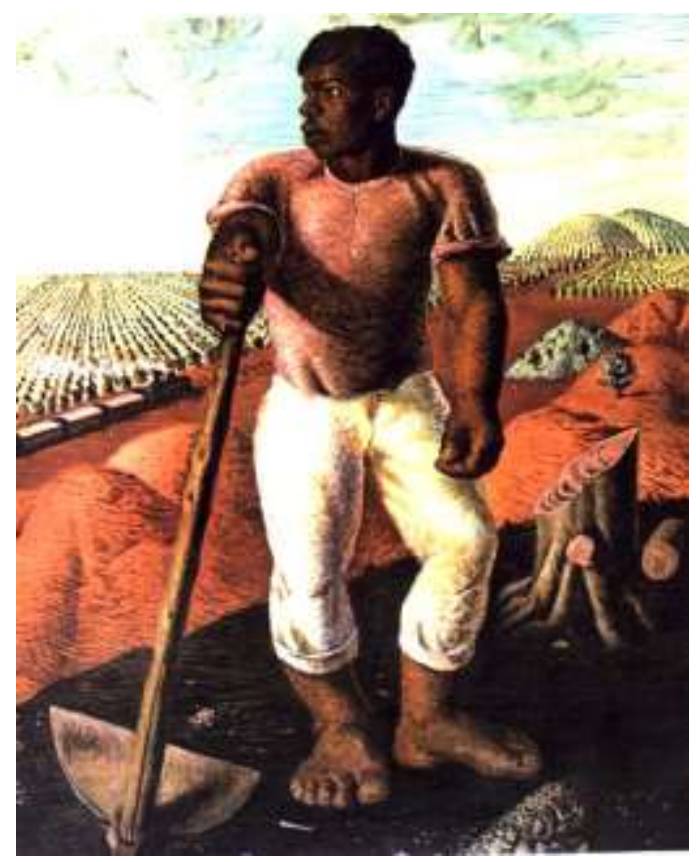

Fonte: ARTE, 2014.

O pós-modernismo se amplia no movimento chamado "contra cultura" que além da arte inclui também o campo social em geral tendo como alvo o "moderno" identificado com o sistema burguês. Várias faces desse movimento: arte pop, música pop; no cinema, a "nouvelle vague" francesa, o neorrealismo italiano; o novo romance, a pintura, culminando com os protestos de massa, que teve seu auge no levante da juventude em 1968 em Paris e outras capitais. ${ }^{2}$

\subsection{Na economia}

O sistema produtivo caminha para um "pós-capitalismo", entendido não como ruptura do sistema, mas como uma nova face denominada pós-industrial que se caracteriza pela produção massiva de bens de consumo de curta duração, pela tele-tecno-ciência, pela sociedade do conhecimento informatizado, pelo

\footnotetext{
${ }^{2}$ Ver Steven Connor (1993) - Professor de cultura e arte em Londres. Ver também David Harvey (2000). - Professor da Universidade de Oxford.
} 
rompimento das fronteiras (mercados comuns e globalização) pela flexibilização do sistema empresarial...3

\subsection{Na filosofia}

Quatro importantes filósofos pós-modernos podem ser focalizados, apontando suas contribuições para um novo pensar sobre a religião hoje.

\section{a) Jacques Derrida}

O mais famoso entre os pós-modernos. Nasceu em Biar, Argélia, 1930. Faleceu em Paris em 2004. Mais de cem títulos publicados. É o filosofo mais traduzido no mundo. De família judaica sofreu as consequências do antissemitismo durante a segunda guerra mundial. Em 1952 está em Paris onde finaliza seus estudos universitários aprofundando-se em Husserl, Kierkegaard e Heidegger. Lecionou na Sorbonne (1960-1964) depois na Escola Normal Superior de Paris (1964-1984); de 1984 a 2003 foi diretor de Estudos da Escola de Estudos Superiores em Ciências Sociais de Paris. Desde o final dos anos 1960 tornou-se professor convidado das mais prestigiadas universidades dos Estados Unidos e da Europa. Esteve no Brasil três vezes, duas em São Paulo (USP e PUC) e outra no Rio. Inúmeros doutorados Honoris Causa.

Na síntese do seu pensamento, destaca-se o tema da desconstrução. Ela não deve ser confundida com destruir, implodir, dissociar, desarticular. Trata-se de uma postura crítica, um despojar do supérfluo para a construção de algo novo. Não é ceticismo nem niilismo. Em Papel- Maquina (2004) Derrida a compara à "destructio" luterana. Lutero desconstruiu, isto é, submeteu a uma crítica radical os aspectos corrompidos agregados pelo velho edifício do catolicismo a fim de levar a Igreja à genuína fé da comunidade primordial. O alvo da desconstrução é a

${ }^{3}$ Ver Krishan Kumar (1997) e Jean-François Lyotard (1993). 
metafísica em sua postura logocêntrica, isto é, fixada no absolutismo da razão. O objetivo é fazer emergir o Ser na sua existência concreta. Nesse aspecto, a desconstrução retoma a posição antimetafísica de "Ser e Tempo" de Heidegger. O ser é um fenômeno vital, o humano lançado na existência. $\mathrm{O}$ ser se expressa na palavra que é a sua morada.

Derrida opta pela filosofia da ausência em vez da metafísica da presença. Ausentar-se não significa fugir da realidade, mas estar em permanente transformação. A filosofia excede inexoravelmente qualquer instituição filosófica e o filosofo não pode tornar-se simplesmente um professor que repete filosofias, mas um facilitador do pensamento reflexivo4. Derrida opta pela escritura em vez da fonética, pois o fonos ou a palavra falada teria sido sempre o suporte da metafisica, Trabalha na filosofia a ideia de diferença que leva a uma arque escrita anterior a qualquer escritura. São teses que ele foi desenvolvendo a partir da matriz fenomenológica de Husserl, e em outros escritos como A voz e o fenômeno (1967), A escritura e a diferença (1967) no qual faz um amplo e profundo estudo sobre Levinas, Margens da Filosofia (1972). As posições de Derrida mereceram críticas de Jürgen Habermas em seu livro O Discurso Filosófico da Modernidade, no qual lhe dedica um capítulo (cap. VII) com o título: "A suplantação da filosofia primeira temporalizada: a crítica de Derrida ao Fonocentrismo".

\section{b) Jean-François Lyotard}

Lyotard nasceu em Versalhes (França), em 1924, e faleceu em Paris em 1998. Vários livros escritos e inúmeras participações em outras publicações. Professor na Faculdade de Letras de Paris, Pesquisador do Centro Nacional de Pesquisas Científicas (Paris), Professor visitante em famosas universidades, inclusive na USP.

${ }^{4}$ Ver Jacques Derrida (1986). 
Com esse autor há a explosão da controvérsia sobre pós-modernidade. Até o final da década de 1970 a controvérsia se limitava a algumas críticas a Derrida, mas não atingiam diretamente a pós-modernidade. O estopim da polêmica foi o livro $L a$ condition post-moderne (A condição pós-moderna) publicado por Lyotard na França, logo traduzido em Inglês pelo crítico literário marxista Fredrick Jameson, e em Português pela Ed. José Olympio. As críticas a essa obra na década de 1980 foram muitas especialmente de Habermas, cuja teoria do agir comunicativo como base de um consenso universal para uma sociedade mais justa foi diretamente criticada por Lyotard no final do seu livro Diante das críticas, Lyotard se viu obrigado a publicar em 1986 um livro de autodefesa com o título irônico: $O$ pósmoderno explicado às crianças 5 .

Sua tese central é que os grandes discursos, também chamados de metanarrativas, porque dão suporte a todas as outras, que sustentavam o saber científico, entraram em crise e estão em extinção. Quais narrativas?

$\Rightarrow$ A narrativa política ou libertária. O povo como sujeito e agente da emancipação. É herança da revolução francesa na qual o povo (a burguesia) proclama a liberdade e se torna seu paladino. Narrativa que posteriormente foi assumida pelo marxismo, que acolherá o "proletariado" como sujeito da emancipação do jugo do capitalismo.

$\Rightarrow$ A narrativa filosófica. Advém do iluminismo que penetrou nas universidades e sustentava o saber através do idealismo. Este proclamava como fundamento da ciência a "vida do espirito" ou "a vida divina”. A realidade social era lida e interpretada mediante estes discursos que se impunham ao saber científico.

Por que a crise e a extinção dessas narrativas? Porque o novo sistema produtivo, a sociedade pós-industrial é eminentemente pragmática. A ciência se

${ }^{5}$ Traduzido em português pela ed. Dom Quixote - Lisboa. 
torna tecnociência, altamente sofisticada e inteiramente voltada para a produção, o consumo e a acumulação da riqueza.

Não havendo mais a legitimação do saber pelas metas narrativas, a ciência se fragmenta em infinitos jogos de linguagem particulares, que se enfrentam sem nenhuma possibilidade de um consenso universal. A lógica do antigo sistema é substituída pela paralogia, isto é, pelo incerto, pelo ilógico. A única legitimação é o desempenho, a eficiência. Vence o mais eficaz e o mais produtivo.

\section{c) Jean Baudrillard}

Baudrillard nasceu em Reims (França), em 1929 e morreu em Paris, em 2007. De família camponesa, formou-se na Sorbonne. Sociólogo, filósofo, poeta, fotógrafo. Personalidade fechada e reservada. Professor na Universidade de Paris X Nanterre, notabilizou-se como conferencista internacional sendo entrevistado pelos mais famosos órgãos da imprensa. Esteve no Brasil várias vezes fazendo conferências e dando entrevistas. Seus livros, mais de 30, são provocadores e polêmicos. O mais famoso, Simulacros e simulação (1981), teria inspirado o enredo do filme "Matrix" e "O show de Truman". Como fotógrafo, fez inúmeras exposições na França e no Mundo.

Destaca-se sua posição sobre a sociedade dos simulacros. A sociedade atual está imersa em simulacros e simulações da realidade. O real está morto. Só temos signos (ou fotografias) sem significados Diz ele em As estratégias fatais (1991, p. 11) "Aceito, analiso, assumo a segunda revolução, a do século $X X$, a da pósmodernidade, que é o imenso processo de destruição do sentido[...] A cena dialética e a cena crítica estão vazias. Já não há cena”. No Brasil, principal comentador de Baudrilllard é Muniz Sodré. 


\section{d) Gianni Vattimo}

Gianni Vattimo nasceu em Turim (Itália), em 1936. Graduado em filosofia na Universidade de Turim Especializou-se na Alemanha com Karl Löwith e HansGeorg Gadamer cujo pensamento introduziu na Itália. Professor de Estética e Filosofia Teorética na Universidade de Turim. Professor visitante em varias universidades dos Estados Unidos. Diretor da Rivista di Estetica. Escreve para o semanário L'Espresso, para o diário La Stampa. Foi católico militante na juventude. Depois, contestando o moralismo sexual do catolicismo tradicional afastou-se da prática e hoje está filiado à Igreja Valdense, um ramo do protestantismo que tem uma atitude liberal com relação ao homossexualismo.

Tem várias obras escritas sendo as principais, O fim da modernidade (1985), A Sociedade Transparente (2000), Acreditar em acreditar (autobiografia do seu itinerário religioso), O Futuro da Religião, escrito com Richard Rorty.

Qual o núcleo do seu pensamento? A partir das filosofias de Nietzsche e de Heidegger, Vattimo acredita que se instaura uma crise irreversível nas bases cartesianas e racionalistas do pensamento moderno. Alvo da sua critica é o pensamento metafisico: o platônico, o aristotélico, o Iluminismo que reduzem a essência da realidade a um universalismo abstrato, a uma racionalidade absoluta e absolutista (pensamento forte) e desconsideram que o Ser está sempre situado e datado. Esse universalismo tem como consequência a dissolução das diferenças, a opressão dos mais fracos, do feminino, da homossexualidade (apontada como desvio doentio) implantando assim uma moral rígida e opressora.

Sempre se inspirando em Nietzsche e Heidegger, Vattimo vê o Ser e o mundo como "evento", "acontecimento" como projeto jamais acabado, que rompe a clausura do mundo técnico e científico e abre possibilidades históricas imprevisíveis sempre novas. Essa concepção da eventualidade do ser ele denomina de "pensiero debole”, pensamento frágil, em oposição à truculência da razão metafisica e iluminista. 


\section{Pós-modernidade não}

Vários autores se posicionam criticamente em torno da pós-modernidade e chegam a recusá-la. Destacam-se Habermas, Eagleton e também alguns críticos no Brasil.

\section{a) Jürgen Habermas}

Nascido em Dusseldorf, Alemanha, em 1929, Habermas é doutor em Filosofia (Bonn), com uma tese sobre Schelling, "O Absoluto e a historia”. Integrou a Escola Crítica da Sociedade de Frankfurt, de 1956 a 1959 onde foi assistente de Theodor Adorno. Em 1968, leciona no New School for Social Research de Nova York. Em 1983, na Universidade Goethe de Frankfurt até se aposentar em 1994. Considerado o mais importante herdeiro da Escola de Frankfurt, entretanto, afastou-se da crítica que essa Escola movia ao Iluminismo, e reafirma o potencial emancipatório da razão.

Rejeita a pós-modernidade como um todo porque a modernidade ainda persiste e é um projeto inacabado. Apesar dos excessos do Iluminismo acredita que a razão iluminista ainda tem um papel fundamental para criar um agir comunicativo, um discurso capaz de levar a humanidade a um consenso para melhorar a sociedade despertando uma consciência moral e o sentido de justiça.

\section{b) Terry Eagleton}

De origem inglesa, Eagleton nasceu em Selford (Inglaterra) em 1943. Filósofo e Crítico Literário de tendência marxista. Seu livro mais conhecido é Teoria da literatura. Uma introdução (1996) em que faz a história do texto contemporâneo desde os românticos até os pós-modernos da última década do século passado. Embora identificado com o marxismo mostra-se simpático ao 
desconstrucionismo de Derrida. Formou-se em Cambridge e é Professor de Inglês na Universidade de Oxford.

Em 1996 escreve As ilusões do pós-modernismo. Em especial no capitulo quinto, "Falácias” e no capitulo sexto, “Contradições”, critica a pretensão dos pósmodernos de abolir toda hierarquia confundindo-a com elitismo, o que seria cair na anarquia. Critica também a tentativa de negar todas as grandes narrativas, pois elas persistem. Há proposições que se aplicam em todos os lugares e em todos os tempos.

\section{c) Críticos no Brasil}

No Brasil, especialmente na educação, há uma tendência a assumir as posições habermasianas. Critica-se o relativismo, a destruição do sujeito, a ausência de projetos e de busca de um caminho libertário ${ }^{6}$. Pelos motivos expostos, os marxistas em geral, embora simpatizando com algumas posições pósmodernas, como o desconstrucionismo, se mostram críticos e contrários às teses pós-modernas.

\section{Posição intermediária. Sim. Com ressalvas}

Não se pode falar de pós-modernidade como um novo ciclo da história. O paradigma moderno de sociedade, o capitalismo, ainda está em vigor apesar das suas crises. E tornou-se hegemônico com o fim da guerra fria e a queda do muro de Berlim (1989). A cultura atual, embora com novas faces (o pós-modernismo) ainda gravita em torno do capitalismo. Como cultura de massa manipulada pelo capital seu alvo principal é produzir-consumir, acumular. O grande relato iluminista não é mais hegemônico, mas não desapareceu, assim como o relato libertário marxista

${ }^{6}$ Ver Pedro Goergen (2005). 
ainda existe. A modernidade ainda está viva apesar das suas crises. Não há um novo ciclo histórico "pós”.

Mas há vários temas, indícios, que possibilitam admitir um pós, ou algo novo na história. Enfim a modernidade não é mais aquela anterior aos anos 1950. Sinteticamente:

a) A própria adjetivação da modernidade indica algo novo: Ex. "modernidade líquida" (Bauman), "radicalizada" (Giddens em As consequências da modernidade, 1991); "neo-modernidade" (Rouanet). "hiper modernidade" (Lypovestky).

b) Pós-modernidade não é um novo ciclo, mas um conjunto de temas que fazem admitir um "clima pós-moderno" Quais?

b.1 O capitalismo, desde os anos 1950 assume novas "faces": economia do consumo massivo, globalização do mercado, comunidades mercadológicas (Mercosul, Mercado comum europeu; asiático etc.); produção de utilizações não duráveis ou descartáveis (ex. celular); velocidade na locomoção; conquistas espaciais, sociedade do conhecimento baseada na extraordinária expansão das informações (informática e informatização: tevê a cabo, satélites de comunicação). Já estamos na aldeia global prevista por Marshal Mac-Luhan, embora profundamente desunida. Com um "sorriso" pós-moderno, esse capitalismo aponta para "um modo de ser imperial, cujo espirito oprime e vitimiza especialmente aqueles que ficam mais expostos às suas iniquidade e injustiças 7

b.2 Reflexos no ser humano: a transitoriedade nas relações ("instant sex" à imagem do "fast food"), as uniões matrimoniais cada vez mais provisórias, o efêmero na moda e nos costumes, a desagregação familiar, o nomadismo também na religião apesar dos fundamentalismos radicais; esvaziamento da visão de classe, partido, pátria; protestos e manifestações setoriais muitas vezes sem sentido político e sem rumo.

${ }^{7}$ Ver Nestor Miguez. Joerg Rieger e Jung Mo Sung 2012. 
b.3 Para além do niilismo. A relevância dos temas pós-modernos.

A desconstrução não é o fim da razão nem do universalismo, mas contesta o absolutismo da racionalidade e da universalidade para dar espaço às diferenças, construindo assim um horizonte de justiça.

O pensamento frágil oferece um caminho ontológico para enfrentar a violência e postula uma religião e uma moral enfocadas no diálogo, na amizade, superando as imposições repressivas.

A ciência pós-moderna abre horizontes para uma nova epistemologia que vai além do formal e do lógico e admite as contradições, o imprevisto, o "indecidível" (teorema de Gödel) e abre espaço para o dissenso, evitando o pensamento único e a homogeneidade cultural. Acolhe os relatos particulares respeitando os hibridismos e os sincretismos.

No pós-moderno incluo Edgar Morin e a teoria da complexidade que se opõe ao pensamento disjuntivo (ou isto ou aquilo), e admite o terceiro incluído propondo um saber e um agir dialógico eis que não há separação da parte e do todo. O universo é um grande tecido ("complexus", quer dizer "tecer junto") que entrelaça ordem e caos, beleza e feiura, harmonia e desafino, o bem e o mal, a sabedoria e a demência, o relativo e o absoluto, o certo e o incerto. Cada solução faz despontar novas inquietações e incertezas, perguntas, problemas $^{8}$. Neste vasto horizonte, aparecem também discursos filosóficos focalizando Deus e a religião.

\section{PARTE II - DEUS, RELIGIÃO E SAGRADO EM ALGUNS FILÓSOFOS PÓS-MODERNOS}

O encontro na Ilha de Capri em 1994, que durou três dias, com o objetivo de refletir sobre o assim chamado "retorno da religião", reuniu importantes filósofos pós-modernos e contou com a participação de Hans-Georg Gadamer.

${ }^{8}$ Ver em especial Edgar Morin, 2003. 
Coordenadores do encontro foram Derrida e Vattimo. As exposições foram reunidas no livro A Religião O encontro de Capri, publicado em 1996, em Francês e Italiano, traduzido e publicado no Brasil em 2000 pela ed. Estação Liberdade. Contém profundas (e difíceis) reflexões sobre Deus, o sagrado, a religião. Teve boa repercussão na Europa, mas pouca no Brasil. Focalizaremos apenas os três primeiros textos do livro.

\section{Jacques Derrida}

"Fé e saber. As duas fontes da religião nos limites da simples razão" (In Derrida e Vattimo -Orgs.- A religião. O encontro de Capri, 2000, p. 11-35). Texto difícil, desafiador e profundo recorrendo a artifícios de linguagem e a vocábulos novos que ultrapassam a significação comum.

A religião como "revelabilidade" e suas imagens.

\section{Figura 3 - Bíblia Sagrada}

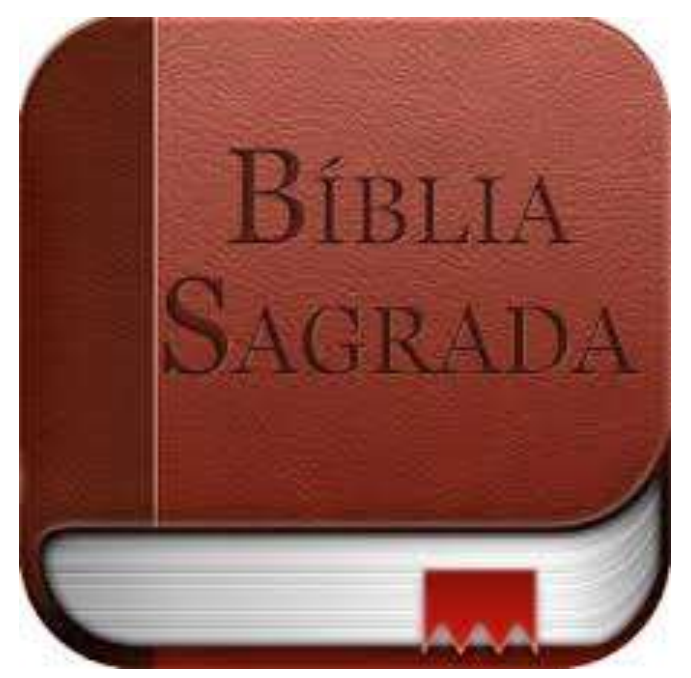

Fonte: GOOGLE IMAGENS, 2015.

Assim como a realidade, para escapar da clausura metafísica, deve buscar uma arque escrita, um livro escrito no universo e anterior a qualquer enunciado e fala metafísica, também as religiões, em seu novo impulso ou "retorno", deveriam 
buscar uma "revelabilidade" anterior a todas as revelações históricas. Para evitar os fundamentalismos que provocam as guerras entre as religiões, faz-se necessário “desconstruir" (não destruir) as várias revelações, e buscar uma revelação antes da revelação. Não se trata de um fundamento universal, o que levaria a um princípio essencial e único de todas as religiões. Derrida não define esse primórdio, para evitar a postulação de um princípio do qual decorreriam as religiões. Recorre a imagens ou "nomes".

\section{Figura 4 - Deserto}

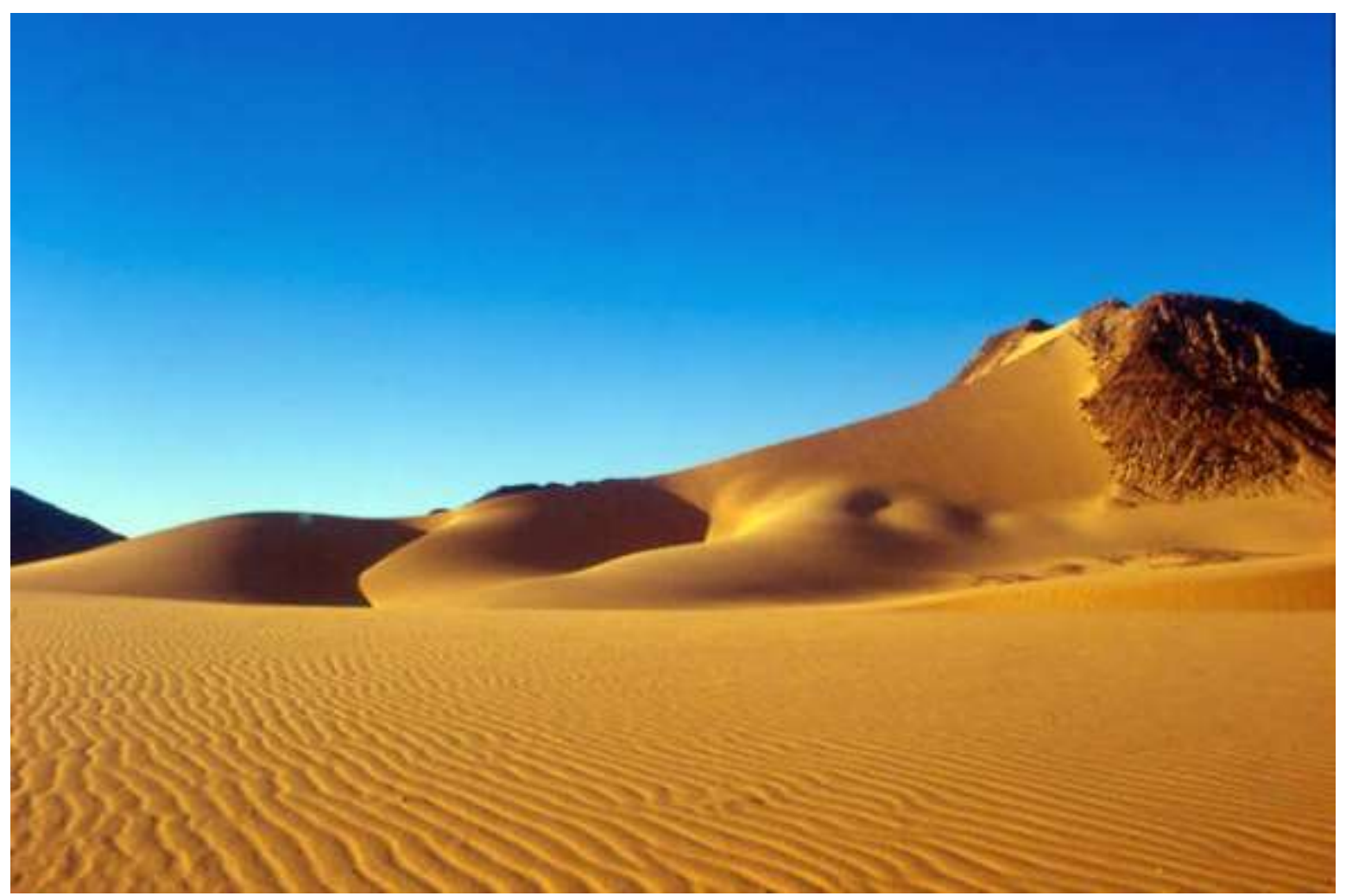

Fonte: DESERTO IMMAGINI, 2015.

Um deserto dentro do deserto. O deserto é uma imensidão. Um deserto dentro do deserto seria o infinito (no meu entender). Um não lugar, anterior a qualquer espaço religioso, lá onde os profetas e os místicos buscam o inefável e o indizível que nenhuma religião tem palavra adequada para expressar. Neste deserto dentro do deserto aparecem outros dois nomes ou imagens que possibilitam captar, ainda que obscuramente, a suprema originalidade do divino. 
Segunda imagem: o messiânico ou a messianidade sem messianismo.

Figura 5 - Figura de Cristo

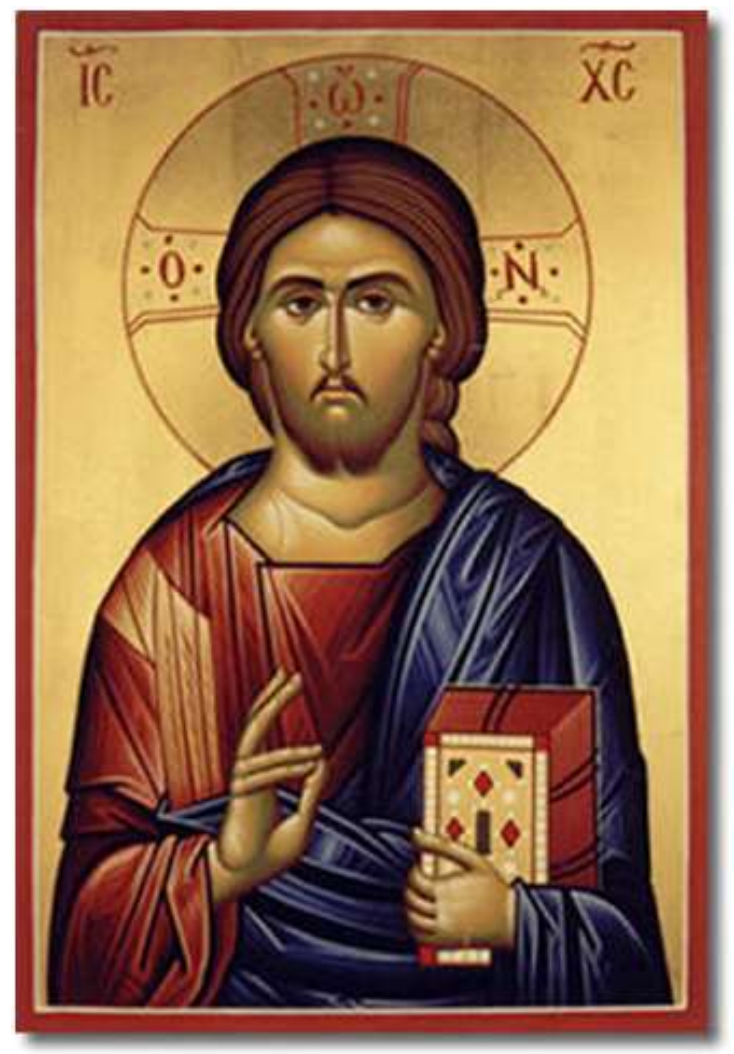

Fonte: ORTODOXOGREGO, 2015.

Trata-se de um messianismo sem nenhum messias histórico. Precede a todas as revelações que a história registra. É apenas uma abertura para o futuro, uma espera da vinda do Outro como advento da justiça. Seria o anseio de uma justiça plena, que deveria ser anterior e estar acima das religiões. Uma surpresa absoluta e anárquica, isto é, sem hierarquia de poder e sem nenhuma determinação ou prescrição religiosa. Embora abstraindo das religiões, esse messianismo inclui uma experiência de fé no Outro e produz uma "cultura universalizável das singularidades”. Despojado de qualquer interesse religioso particular, ele é uma fé sem dogmas. 


\section{Figura 6 - Nebulosa}

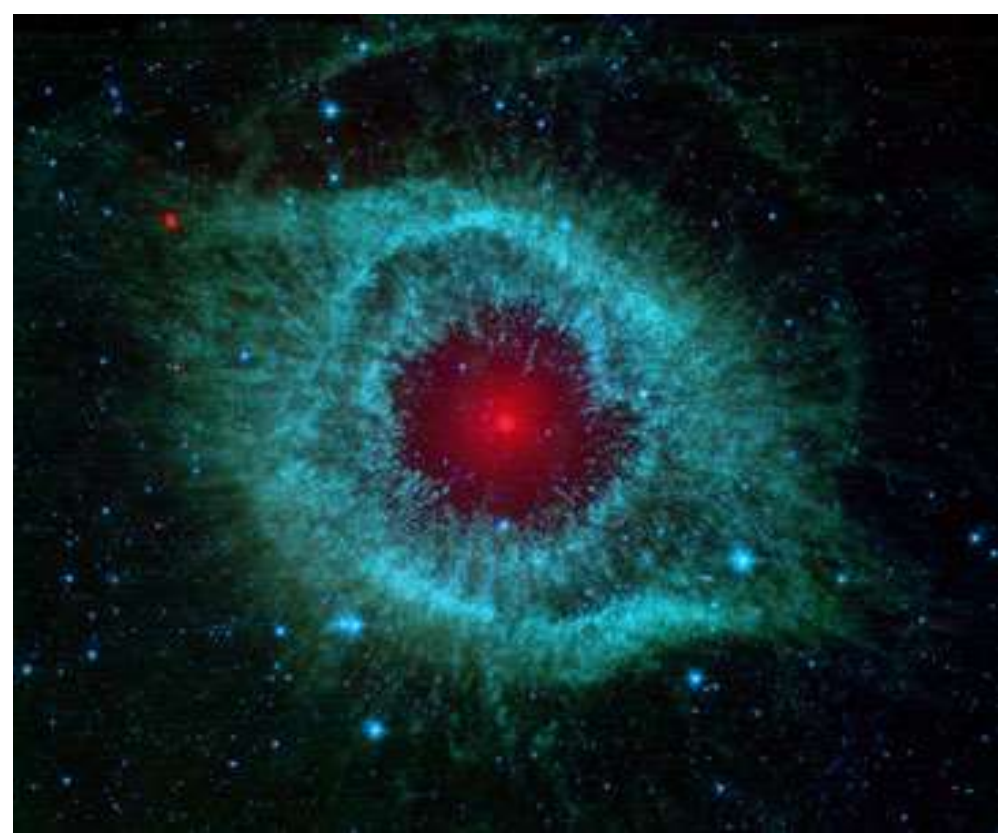

Fonte: ASTRONOO, 2015 .

Khôra. É outra miragem que surge dentro do deserto anterior às religiões. Trata-se de uma imagem enigmática tomada de Platão, no Timeu, o mais obscuro diálogo do grande filósofo. É indefinível. Não é um lugar. É absoluta alteridade e exterioridade, que está além dos seres físicos. Portanto, além do ser religioso concreto. Não é o ser, nem o bem, nem um Deus estabelecido, nem o Homem, nem a Historia. É anterior a qualquer lei religiosa. É algo que não se deixa "sacralizar" nem "teologizar" e resiste a toda tentativa de um absolutismo ou poder religioso.

Hipótese interpretativa a ser desenvolvida numa pesquisa em andamento. $\mathrm{O}$ esforço de apresentar essas imagens pela negação, pelo que não é, soa como algo dentro da teologia negativa, isto é, da teologia que chega a Deus não diretamente, mas afirmando o que ele não é, eis que não há conceitos positivos que possam expressar a sua inefabilidade. Revelabilidade, deserto dentro do deserto, messianismo sem messias, khôra, seriam nomes metafóricos ou imagens que tangenciam, chegam às margens do Deus escondido, inefável, invisível, inexprimível. Esta interpretação parece ter apoio numa frase densa, e um tanto 
obscura de Derrida ao se referir ao deserto no deserto: "A chance desse deserto no deserto (como do que e assemelha ao ponto de se equivocar, mas sem se reduzir a isso, à via negativa que abre aí a passagem a partir de uma tradição greco-judaicocristã) é que, desenraizando a tradição que a transporta, ateologizando-a, essa abstração liberta, sem negar a fé, uma racionalidade universalizável, assim como a democracia politica que lhe é indissolúvel" (Derrida, 2000, p. 31). O que seria essa a-teologia da tradição que transporta a via negativa? Um tema que só uma pesquisa em outros textos de Derrida poderá aclarar. Por isso, para trabalhar a hipótese aventada, a pesquisa buscará analisar outras obras nas quais Derrida aborda diretamente a teologia negativa: Salvo o nome, comentário ao poema de Angelus Silesius intitulado O peregrino querubínico; o estudo sobre Levinas publicado em A escritura e a diferença (sem tradução em português) e o livro Khôra (editora Papirus, 1995) que levam a supor a tese da aproximação de Derrida com a mística judaica9.

Na hipótese da aproximação de Derrida com a mística judaica estarão presentes as duras criticas que move Habermas a sua Gramatologia e as consequências relativas às suas posições no que tange a uma possível superação da metafisica e da ontoteologia que ainda persistiriam no pensamento de Heidegger. Em $O$ discurso filosófico da modernidade afirma Habermas categoricamente: "Derrida crê ultrapassar Heidegger. Felizmente, remonta para aquém dele" (Habermas, 2000 p. 258. Eis outras críticas, a guisa de exemplo; "Como participante do discurso filosófico da modernidade, Derrida herda as debilidades de uma crise da metafisica que não se livra da intenção de uma filosofia primeira" (p. 254). E ainda: "O pensamento desconstrutivo, por meio de formulas vazias, aterra-se na invocação de uma autoridade indeterminada. Todavia esta não é a autoridade de um Ser deslocado pelo ente, mas a autoridade de uma escritura não mais sagrada, de uma escritura exilada, errante, alienada do seu sentido próprio e testemunha testamentaria da ausência do sagrado" (p.254). E prossegue: "a

\footnotetext{
${ }^{9}$ Há comentaristas de Derrida que serão também consultados e entrarão na arena do debate. Por exemplo. John D. Caputo. Ateismo, A/teologia e a condição pós-moderna (, p.347-366). E também de Caputo: The Prayers and Tears of Jacques Derrida:, 1997.
} 
retórica que em Heidegger servia para o exercício no fatum do Ser, favorece em Derrida uma atitude distinta subversiva. Derrida está mais próximo do desejo anarquista de rebentar o continuum da história que da ordem autoritária de se submeter ao destino. Esta atitude contraria pode estar ligada ao fato de que Derrida, apesar de todos os desmentidos, permanece próximo da mística judaica” (p. 255). Que mística seria essa? Segundo Habermas, trata-se de uma mística pagã, herética, que acentua o parentesco de Derrida com a tradição rabínica, e, em particular, com a sua radicalização cabalística e herética”. Ver página 258 e a nota 46 na qual Habermas acolhe as teses de Susan Handelman no seu trabalho Jacques Derrida and the Heretic Hermeneutic

Uma avaliação da veracidade e do alcance dessas injunções de Habermas será objeto da pesquisa em andamento.

\section{Gianni Vattimo}

No livro A religião escreveu o texto: "O vestígio do vestígio” (p.91-107). Sua hipótese: o retorno do sagrado é um aspecto fundamental da experiência religiosa. O retorno (ou melhor, o novo vigor das religiões) poderia ser motivado por "medos apocalípticos”: (ameaça nuclear, devastação ecológica, etc.) ou pela perda do sentido da existência, pelo tédio do consumismo... Ou pela afirmação das etnias locais após a repressão sofrida durante os regimes comunistas. Ou pela reação das culturas ancestrais (hinduísmo, islamismo, budismo...) ameaçadas pela cultura tecnológica ocidental. Ou pela incapacidade da filosofia e das ciências de oferecer um sentido para a existência. Mas o perigo é a regressão para um Deus metafisico, imóvel, soberano, onipotente, alheio a historia e às novas vicissitudes da sociedade e da existência humana, simples projeção dos temores humanos; ou um deus belicoso e até terrorista, à imagem e semelhança das bombas humanas.

Como evitar a recaída nesses deuses? O caminho seria a religião caminhando pela via do "pensiero debole" (pensamento frágil) pelo qual a filosofia descobre o 
divino como um vestígio, como algo eventual e histórico, manifestando-se nos acontecimentos da vida. Um modelo desta descoberta do divino é o evento "encarnatório" do cristianismo pelo qual Deus entra na história e assume plenamente a suas vicissitudes. Aí não temos mais um Deus metafisico, ausente, mas um Deus que se faz frágil e assume nossas fraquezas.

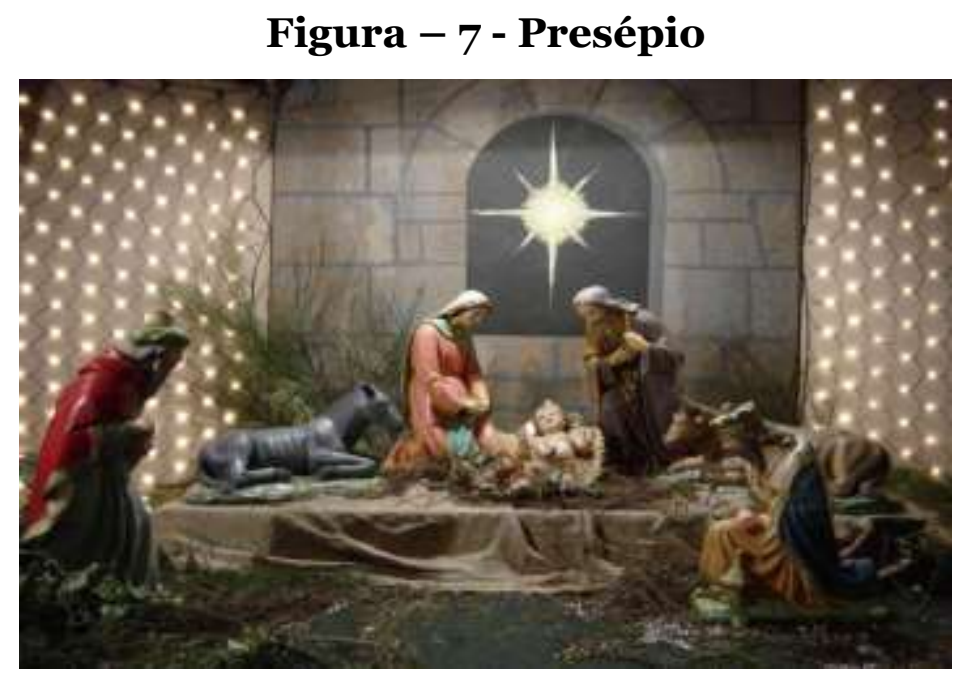

Fonte: IT BABIES, 2015 .

Nesse fato "encarnatório", acontece, segundo Vattimo, um encontro da filosofia com a religião. Diz ele: "parece ser somente à luz da doutrina cristã da Encarnação do Filho de Deus que a filosofia pode se apresentar como uma leitura dos sinais dos tempos, sem se reduzir a um registro passivo do curso dos tempos [...] Deus encarna, revela-se na anunciação bíblica e este fato dá lugar ao pensamento pós-metafísico da eventualidade do ser" (Vattimo, in A religião, 2000 p. 105 e 106).

Comentário. Trata-se de uma tese muito ousada que parece colocar-se na interface entre filosofia, ciência da religião e teologia, até rompendo as tradicionais fronteiras. A referência ao "fato encarnatório", muito envolvente para quem se coloca no âmbito do pensamento cristão pode, porém, soar estranha e até incompreensível para os monoteísmos judaico e islâmico e para as religiões orientais tais como o budismo, o hinduísmo, alheias a este "fato encarnatório". 


\section{Eugenio Trias}

Texto "Pensar a religião. O símbolo e o sagrado" ( In A religião, p. 109-134). Trias nasceu em Barcelona, em 1942, e faleceu em 2013. Considerado o escritor de língua espanhola mais importante depois de Ortega Y Gasset. Doutorado em filosofia em Barcelona. Pós-graduação em Madri, Bonn e Colônia. Em 1972-1973 fez conferências no Brasil e na Argentina. Professor de Estética e depois Catedrático de filosofia na Universidade de Barcelona. Tem uma visão enciclopédica da filosofia nos seus mais de 30 livros, nos quais trabalha estética, reflexões crítico - políticas e filosofia da religião. Apenas três livros foram traduzidos em Portugal.

Questão do texto: o novo vigor das religiões poderia ser explicado pelo seu caráter de ilusão (Freud) ou de ideologia? Seria uma retomada do "ópio do povo" (Marx)? Trias descarta estes estereótipos explicativos por serem simplistas e redutores. Também o "retorno" não deve ser confundido com o recrudescimento do moralismo em certos movimentos religiosos (moralismo islâmico, tradicionalismo católico...).

A tese que propõe para pensar a religião em profundidade na pósmodernidade consiste em refletir o fenômeno religioso mediante uma "palavrachave" que possibilitaria criar o terreno propicio para uma "religião do espirito" em oposição às religiões manipuladas por interesses corporativos e materiais. Diz Trias citando uma célebre frase de Rafael Sánchez Ferlosio: "enquanto não mudarem os deuses, nada muda”. Essa mediação ou palavra-chave é o símbolo. 


\section{Figura 8 - Medalha partida}

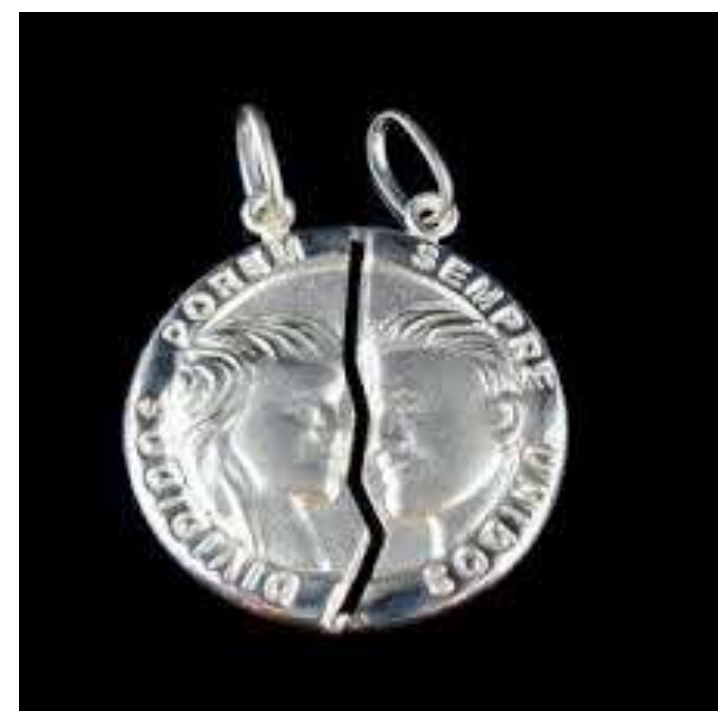

Fonte: TERRA DA PRATA, 2015.

Cumpre, portanto, imaginar o sagrado como um evento simbólico. Assim visto, o símbolo se apresenta como "a revelação sensível e manifesta do sagrado" Podemos imaginá-lo na origem do termo de maneira escultural, no ato de simbolizar. Nos primórdios ele era representado pelo ato de juntar dois pedaços de uma medalha partida significando uma aliança que se ausentou e depois se reencontra. A parte desta medalha que ficou disponível é o simbolizante do símbolo. A outra parte que ficou ausente é a parte simbolizada ou o horizonte de sentido. O símbolo, portanto, é uma unidade que supõe uma cisão anterior. A ausência do simbolizado remete a um cenário de exilio. $\mathrm{O}$ exilio termina com a unificação. Assim como a medalha partida, o mundo também é um universo partido. O sagrado está ausente. Ele se faz presente mediante as revelações, um processo que torna possível o acontecer simbólico, a junção das partes. O sagrado e a religião não constituem um processo estático. São um constante acontecer simbólico. Um encontro contínuo. O simbolizante, ou a parte material do símbolo, está sempre presente mediante formas, figuras, traços, palavras. Constitui a matriz, a parte material do símbolo. O seu suporte físico. O simbolizante anseia por receber a forma, a figura simbólica. O substrato material, em si carente de sentido, está aberto à espera de ser ordenado e se transformar em cosmo. Está à espera do 
templo (em grego "temenos") que é a demarcação do espaço sagrado e conduz ao tempo sagrado (a hora, o tempo, a festa, o ritual). Nesse "templo" - tempo ou espaço sagrado -, o mundo material se transfigura.

O acontecimento sagrado sempre se realiza em um cenário Nesse cenário temos a presença do sagrado que se revela, e uma testemunha humana que acolhe e especifica a sua forma e figura. Essa mediação humana que acolhe a revelação pode ser oral ou escrita. O testemunho, pela palavra ou revelação, consuma o processo simbólico. Esse processo consumado sempre está sujeito a interpretações. Ai entra o exegeta, o historiador, o sociólogo, o cientista da religião, o filosofo, o teólogo a descobrir e analisar o fenômeno simbólico.

Enfim, interpretando o pensamento do filósofo Trias, caberia à religião como processo simbólico, por sua força de união neste mundo fragmentado e profundamente dividido, a tarefa de revitalizar o ser humano e a sociedade descobrindo um horizonte de sentido.

\section{Concluindo sem finalizar}

Assumindo uma posição no debate que continua sobre a pós-modernidade, o texto a caracterizou como um clima no âmbito da modernidade que a transcende sem a pretensão de constituir uma nova idade histórica. O pós-moderno consiste em temas novos caminhando à margem e amiúde em direção oposta aos parâmetros da modernidade, temas presentes em vários campos do saber e do agir humano inclusive na teologia e nas ciências da religião ${ }^{10}$. Apontou, a guisa de exemplificação, três notáveis filósofos pós-modernos que manifestam suas posições sobre o divino e buscam interpretar o novo vigor que vem assumindo a religião na atualidade. A terceira parte do texto, ainda em gestação, vai focalizar especificamente o filósofo Jacques Derrida indagando sobre suas posições e em

\footnotetext{
10 O maior número de obras nessa linha está no campo da teologia. Cito algumas: Hans Küng, 1984; José Maria Mardones, 1988; Jaci
} Maraschin e Frederico Piper Pires, 2008; e Geraldo Luiz De Mori, 2005. 
especial sobre sua possível aproximação com a teologia negativa e a mística judaica.

\section{REFERÊNCIAS}

ARTE - Fonte de Conhecimento. Andy Warhol. Disponível em: $<$ http://artefontedeconhecimento.blogspot.com.br/2010/12/andy-warhol.html>. Acesso em: 25 jul. 2015

ARTE - Fonte do Conhecimento. O Lavrador de Café de Candido Torquato

Portinari. Disponível em: <http://artefontedeconhecimento.blogspot.com.br/2011/10/olavrador-de-cafe-candido-portinari.html>. Acesso em: 12 dez. 2014

ASTRONOO. Nebulosas. Disponível em:

<http://www.astronoo.com/pt/nebulosas.html>. Acesso em: 25 jul 2015

BAUDRILLARD Jean. As estratégias fatais. Lisboa: Editorial Estampa, 1991.

BAUDRILLARD Jean. Simulacros e Simulações. Lisboa: Editora Relógio d'Água, 1991.

CAPUTO, John D. Ateismo, A/teologia e a condição pós-moderna. In: MARTIN, Michael (Org.). Um mundo sem Deus. Ensaios sobre o Ateismo. Lisboa: Edições 70, 2010. p.347366.

CAPUTO, John D. The Prayers and Tears of Jacques Derrida: Religion without Religion. Bloomington, Indiana University Press, 1997.

COUNNOR, Steven. Cultura Pós-Moderna. Introdução à teoria do contemporâneo. São Paulo: Loyola, 1993.

DE MORI, Geraldo Luiz, A teologia em situação de pós-modernidade, Cadernos de Teologia Pública, Ano II, n. 11, Porto Alegre, Unisinos, 2005 - disponível no Portal FAJE.

DERRIDA, Jacques. Les antinomies de la discipline philosophique, Paris: Osiris, 1986.

DERRIDA, Jacques. A Escritura e a Diferença, $2^{\text {a }}$ edição, São Paulo: Perspectiva, 1995.

DERRIDA, Jacques. A voz e o fenômeno. Rio de Janeiro: Zahar, 1994.

DERRIDA, Jacques. Fé e saber. As duas fontes da religião nos limites da simples razão. In Derrida e Vattimo. A religião. O encontro de Capri. São Paulo: Estação Liberdade, 2000, p. 11-35.

DERRIDA, Jacques. Gramatologia. São Paulo: Perspectiva, 2011

DERRIDA, Jacques. Margens da Filosofia. Campinas/ SP: Papirus, 1991.

DERRIDA, Jacques. Salvo o Nome. Campinas/ SP: Papirus 1995. 
DERRIDA, Jacques. Papel - Máquina. São Paulo: Estação liberdade, 2004.

DESERTO IMMAGINI. Related Keywords \& Suggestions. Depositphotos. Disponível em: <http://www.keyword-suggestions.com/ZGVzZXJobyBpbW1hZ2luaQ/>. Acesso em: 25 jul. 2015.

EAGLETON, Terry. As ilusões do pós-modernismo. Rio de Janeiro: Zahar. 1998. GIDDENS, Anthony. As consequências da modernidade. $2^{\mathrm{a}}$ ed. Porto Alegre: Sulina, 2003.

GOERGEN, Pedro. Pós-Modernidade, ética e educação. 2.ed. Campinas: Autores Associados, 2005

GOOGLE IMAGENS. Bíblia Sagrada Grátis - Android Apps on Google Play. Disponível em:

<https://www.google.com/imgres?imgurl=https\%3A\%2F\%2Flh3.ggpht.com\%2FSlIVPniO pLODDNAkfv2-DNgL_9GgK7xgIq-hS4q2mZ59mSaYlgdUxVrc6-

zvFs8U6OA\%3Dw30o\&imgrefurl=https\%3A\%2F\%2Fplay.google.com\%2Fstore\%2Fapps\% 2Fdetails\%3Fid\%3Dcom.tvrsoft.bibliasagrada\&docid=4DOOExkpB-lx4M\&tbnid=n1xVoQFEdQ-XM\%3A\&w=300\&h=300\&hl=pt-BR\&bih=638\&biw=1366\&ved $=$ oahUKEwjyc2ag8_PAhXCIpAKHTlZBewQMwheKCEwIQ\&iact=mrc\&uact=8>. Acesso em: 25 jul. 2015 .

HABERMAS, Jürgen. O Discurso Filosófico da Modermidade. São Paulo: Martins Fontes, 2.000.

HARVEY, David. A condição pós-moderna. Uma pesquisa sobre as origens da mudança cultural. São Paulo: Loyola, 2000.

IT BABIES. Presépios. Disponível em: <https://itbabies.net/tag/presepios/>. Acesso em: 12 dez. 2014.

KUMAR, Krishan. Da Sociedade Industrial à Pós-Moderna. Novas Teorias sobre o Mundo Contemporâneo. $4^{\mathrm{a}}$ ed. Rio de Janeiro: Zahar, 1997.

KUNG, Hans, Teologia para la pos-modernidad. Madrid, Alianza Editorial, 1984.

LYOTARD, Jean-François. O pós-moderno explicado às crianças. $2^{\mathrm{a}}$ ed. Lisboa: Dom Quixote, 1993.

LYOTARD, Jean-François. A condição pós-moderna. $4^{\text {a }}$ ed. Rio de Janeiro: José Olimpio, 1993.

MARASCHINI, Jaci; PIRES, Frederico Piper, Teologia e Pós-modernidade. Novas Perspectivas em Teologia e Religião. São Paulo. Fonte Editorial.

MARDONES, José Maria. El desafio de la pós-modernidade para el cristianismo. Santander, Sal Terrae, 1988. 
MIGUEZ, Nestor; RIEGER, Joerg; MO SUNG. Jung. Para além do espirito do Império. Novas perspectivas em politica e religião. São Paulo: Paulinas, 2012.

MORIN, Edgar. O Método 5. A humanidade de humanidade, a identidade humana. $2^{\mathrm{a}}$ ed. Porto Alegre: Sulina 2003.

ORTODOXOGREGO. Os Santos Ícones. Disponível em:

<https://ortodoxogrego.wordpress.com/2011/05/o7/os-santos-cones/>. Acesso em: 25 jul. 2015 .

TERRA DA PRATA. Medalha Namorados em Prata. Disponível em: 25 jul. 2015. <http://www.terradaprata.com.br/medalha-namorados-em-prata.html >. Acesso em:

TRIAS, Eugênio. Pensar a Religião. O símbolo e o sagrado. In DERRIDA E

VATTIMO (Orgs). A Religião. O encontro de Capri. São Paulo: Estação Liberdade, 2.0oo, p. 109-124.

VATTIMO, Gianni. Acreditar em acreditar. Lisboa: Relógio D’Água, 1998.

VATTIMO, Gianni. O vestígio do vestígio. In: DERRIDA e VATTIMO (Org.). A Religião. O Encontro de Capri. São Paulo: Estação Liberdade, 2000. p. 91-107.

VATTIMO, Gianni. RORTY, Richard. O futuro da religião. São Paulo: Dumará, 2006.

VATTIMO, Gianni. La società trasparente. $3^{\mathrm{a}}$ edição. Milão: Editora Garzanti, 2.ooo.

VATTIMO, Gianni. O fim da modernidade. Nihilismo e hermenêutica na cultura pósmoderna. São Paulo: Martins Fontes, 1996. 